\title{
People vs God: the logic of 'divine sovereignty' in Islamic democratic discourse
}

\section{RAJA BAHLUL}

ABSTRACT This paper aims at clarifying the role which the concept of 'divine sovereignty' plays in the discussions which are taking place among Islamic thinkers (and others) concerning the possibility of democracy in an Islamic context. It argues that 'sovereignty' has at least two meanings, one 'factual', the other 'nomative'. The paper also argues that the second sense of 'sovereignty' allows us to constme talk of 'divine sovereignty' as an attempt by Islamic thinkers to go beyond the merely procedural views of democracy which focus on the familiar procedures of power contestation, election and accountability.

\section{Introduction}

Islamic thinkers who want to come to terms with democracy are often thought to face the following difficulty. On the one hand, democracy requires the upholding of a principle of popular sovereignty. In a democracy the people are supposed to rule-over themselves, of course. They freely give laws to themselves, and they freely obey them. They are subject to no power but their own. Islam, on the other hand, seems to require repudiation of popular sovereignty in favor of something which is sometimes referred to as 'divine sovereignty'. Fundamentalist Islamic thinkers often use the slogan alhăkimiyya $l i-l l a \bar{a} h$, which may roughly be rendered as 'sovereignty (rulership) belongs to God', in order to stake an anti-democratic position, and most readers have no difficulty in grasping the point which lies behind this slogan, viz., to warn against secularist ideas that do not acknowledge 'God's rule' over Muslim society.

For those who think that 'Islamic democracy' is an incoherent concept, this is just one more illustration of the gulf which separates Islam and democracy. But for those who think otherwise there is a conceptual problem to solve, namely, to give an account of the notions of popular and divine sovereignty which clarifies both, and shows that the seeming conflict between them is more apparent than real. In this article I want to look at the notion of divine sovereignty as used by some Islamic writers. Several distinctions will be made which will hopefully shed light on the nature of the difficulty and its significance.

\section{The Notion of Divine Sovereignty}

Let us begin by looking at statements by some leading Islamic theorists which illustrate their notion of 'divine sovereignty'.

In the Qur'ān it is stated: 'O believers, obey God, and obey the Messenger and those in authority over you' (Q. 4:59). This verse establishes the basis of the Islamic social, political, and religious system. It is the legal corner-stone of the Islamic state and constitution. It clearly indicates the center of supreme 
authority in the lives of Muslims ... It also clearly indicates that obedience to the Messenger of God ... is the practical form in which obedience to God cxpresses itself. After this comes the power which the people exercise. The legitimate scope for this power does not violate divine law which is found in the Qu' an and the Traditions of the Messenger. (Ghannouchi 1993, 119)

Naturally, there is no place in Islam for a popular government which is separated from the Faith. Islam is a monotheistic religion which permeates life and views it in its entirety as an act of worship. It organizes life by means of a religious code which does not separate political life from religious life, nor public life from private life... Democracy in Islam does not mean absolute popular power, but rather popular power in accordance with $\operatorname{shari}^{-6} a$ [divine law]. (Turabi 1987, 63-4, 67)

The authority of government is limited because $\operatorname{shar}^{-} a$ is the higher law, just like the constitution except that it is a detailed constitution... The difference between shīra and democracy ... is that the higher law in Islam is so intensive that the legislature has much less to say or do. The legislature, the Congress, or Parliament or whatever, is not sovereign at all. The shari'a governs so much. (Turabi, in Lowrie 1993, 25)

The right of rulership gives rise to the right to legislate to people, the right to prescribe a way for people to live, a right to institute the values which this life is to be based on... Whoever claims for himself the right to legislate a way of life for a people thereby claims divine authority over them, for he seeks to appropriate the most important attribute of divinity. Whoever amongst the people accepts this claim has thereby agreed to make this person a God in place of the true God, for he attributes to him the most important attributes of divinity. (Sayyid Quț, quoted in Abū Zayd 1994, 105)

These texts, and others along the same lines, show that many Islamic thinkers want to draw an opposition between goremmen by people and govemment by God. Either a people govern themselves in accordance with laws of their own making, or they are governed by God in accordance with divine law. If one says that the former ought to be the case, then one expresses belief in 'popular sovereignty'; if the latter, then one admits the sovereignty belongs truly to God, and to God alone. This opposition between 'government by the people' and 'govemment by God' is bound to seem naive to modern readers who do not think in religious terms. To such readers, the real opposition to be drawn is not between government by the people and government by cod. Rather, it is between government by the people and government by a class of clergy, who may be organized in terms of a church (as in the case of Christianity) or may not have any or much of a formal organization (as in the case of Islam).

Many Islamic writers are prepared to join forces with democrats in opposing the 'rule of the clergy'. Believing that Islam has neither church nor clergy, they see no danger of 'priestly government' in Islam. But even if it could be shown that the various classes of rcligious specialists, known as 'ulamā' (who include judges, imāms, muftīs, mujtahids, etc.) play a similar role, some Islamic writers continue to protest sincerely that it is not the ' 'ulamā' who rule in the Islamic state, but God. For the 'ulamä' are as much subject to divine law as the rest of the people and their special knowledge gives them no privilege and grants them no immunities.

This 'believing point of view' should be taken at face value. In fact, I think we have 
no way around this, short of engaging in a discussion of the truth of the religious perspective. Even then, it is hardly likely that such a discussion would lead to results that would be universally accepted. To explain religious categories and distinctions in terms which borrowed from social science (history, sociology, psychology, etc.) is a large project whose success is far from certain. Besides, it is not something that we need to assume for our present purposes. Let us therefore follow Islamic writers in thinking that one can (and should) distinguish between government by the people and government by God. Some questions need to be raised about this. Do we have a case of genuine opposition here? That is, does government by God exclude government by the people and vice versa? Are there other possibilities? On the face of it, it does seem that there is a third possibility which Islamic writers do not dwell on. Suppose that the popular will and the divine will coincide, in the sense that what the popular will chooses is nonc other than divine law. If the people freely choose to be governed by God's law, that is, if they take God's law to be their own law, are they exercising popular sovereignty, or are they subject to divine sovereignty, or both? Granted that the people are not the authors of the 'divine laws' which they may freely choose to follow in their life, does this make a difference? In real life we often accept (adopt) arguments which we have not invented or discovered, but which we later use and present to others as our own arguments. Could it be the same with divine laws we may freely follow?

'These are puzzling questions to be clarified in the course of the discussion.

\section{Factual Sovereignty}

In order to disentangle some of the ideas which are brought together by the question of divine vs popular sovereignty, we need to answer a simpler, but nevertheless important question. Is there any way in which Islamic thinkers are willing to attribute to a free people an 'ultimate power' or 'ultimate authority', in some sense or other of these terms? By a 'free people' we do not mean anything extraordinarily moral or metaphysical. We simply mean people not ruled against their will, whether by domestic tyrants or foreign powers. Common sense says that a free pepole are 'sovereign' in the simple and straightforward sense that they can (and, barring unusual circumstances, most likely will) do whatever they make up their 'mind' to do; that such people do not wait upon anybody's permission to do what they want to do. This ability of a free people to carry out whatever their 'political will' decides is independent of the question of whether the political decision is right or wrong, whether it is something which the people ought or ought not to carry out. A people may decide to invade their weaker neighbor, which would be wrong. Or they may decide to respect the freedom of their weaker neighbor, which would be right. They may decide to continue to tive in a democratic way, which would be right. And they may decide to give themselves up to undemocratic rule, which would be wrong. But the right and wrong in all of these matters are different from the question of whether a free people have the power to carry them out, or at least to launch an attempt at carrying them out.

That a free people are sovereign in the sense indicated above may be an obvious point which hardly needs to be belabored. But this point is exceedingly important in the context of trying to lay a foundation for dealing with the somewhat ethereal notion of divine sovereignty, and so we may be excused in dwelling on it a little longer.

Addressing oneself to theologically-minded thinkers who are disinclined to admit a sense in which the people (a free people, that is) are sovereign, one could say: Suppose people decide to give up democracy, what can possibly stand in the way of 
their doing so? 'The Constitution? But that can be amended by the people. The courts? But the judges can be replaced by the people. As Dahl says when he considers the possibility that a majority of people may choose to relinquish the democratic process, "When the democratic process can no longer be sustained in the face of a weak or hostile political culture, it strains credulity to believe that primary political rights will be preserved for long by courts or any other institutions' (Dahl 1989, 173).

()f course, one could think of ways in which a political system may be maintained by sheer force, or oppression, either internal, or imposed by a foreign power. But both ways are inconsistent with a people being politically free, and thus having 'sovereignty' in its own affairs. This is a possibility which is of no relevance to our discussion. The debate between friends and opponents of the notion of 'divine sovereignty' takes place in connection with a people that is able (if it so wishes) to govern itself democratically. We are not interested in what happens (or fails to happen) in a society consisting of powerless slaves or mentally incompetent individuals. Thus it must be acknowledged that regardless of whether we approve of decisions taken by the people, a (free) people do have sovereignty. What impact this has on God's sovereignty, if any, has to be discussed as a separate question. No matter what the outcome of the discussion of the latter question, there is simply no way of getting past the empirical fact that a free people can (and normally will) exercise political power which may correctly be referred Lo) as 'popular sovereignty'

Some Islamic thinkers, at least those who are not determined to turn a blind eye to reality, recognize these facts. Prominent examples of this kind are Muhammad Khatimi, and Rachid Ghannouchi. According to the former:

It is my belief that popular will $[\ldots$ is ... a main condition for the establishment and durability of the state. Of course, I can imagine a state being established contrary to popular will and desire, but I find it difficult to imagine its being a stable and durable state, because it is not wanted in the first place. It is not possible for an Islamic state to come into being, nor can an Islamic state last regardless of the people and what they choose. Besides, nobody can choose a non-democratic path without having recourse to the use of force. There is simply no third way; those who reject the path of democracy are calling for dictatorship and coercion. (Khatimi 1998, 86, 99)

Ghannouchi, on the other hand, is not as explicit as Khatimi. But his 'soul-searching' questions about what Islamic parties should do in the event of their failing to maintain a majority in free elections leave no doubt that he is of the opinion that people ought to have the last say in how they are to be ruled:

What should an Islamic party do if it fails to maintain [obtain] a majority in free elections? Is it supposed to use armed force, or should it reform itself and resume the task of convincing the people of its project? Do Muslims always have to brandish the sword in the face of a non-Muslim majority (or even a Muslim majority) that does not want them to rule over it, when they have the freedom to participate and to spread their message? In other words, where do Islamists derive legitimacy for their rule? Do they derive it from the mere fact that they are Muslims? This is simply a paternalistic way of thinking. Or do they derive legitimacy for their rule from the people? (Ghannouchi 1993, 259)

If we follow both Khatimi and Ghannouchi in thinking that an Islamic state cannot come into existence or have stability against the wishes of the people, does that not 
mean that people have sovereignty, in one sense of the term? According to both authors, people can choose to follow Islam (and with it, God's law) or they can choose not to. In either case the decision belongs to the people. God and 'divine sovereignty', whatever the latter means, have to wait upon the people's choice. Given these commonsensical admissions on the part of Khatimi and Ghannouchi, we conclude that there is at least one sense of sovereignty according to which we can correctly say that a free people have sovereignty. Call this 'factual sovereignty', on account of its having to do with 'the facts', with how things are, or can be, in reality. This leaves us with the task of determining the meaning, if any, which can be associated with the term 'divine sovereignty'. Let us therefore turn to the question: in what sense can God be 'sovereign'?

\section{The Hidden 'Oughts' of Divine Sovereignty}

In order to understand the role which the notion of divine sovereignty plays in the thinking of some contemporary Islamic writers who employ the term, it is helpful to dwell initially on a certain notion of 'validity' or 'moral rightness', as applied to political decisions. (We use these terms interchangeably; there are no commonly agreed-upon idioms to describe the notions and distinctions we shall make presently.) We mean to distinguish between 'validity' (or rightness) on the one hand, and (mere) 'legitimacy', on the other.

'Legitimacy' is a weaker notion than 'validity'. According to Rawls, 'Laws passed by solid majorities are counted as legitimate, even though many protest and correctly judge them unjust or otherwise wrong' (Rawls 1993, 428). Thus legitimacy bears reference to established rules and procedures, in the sense that what is decided through them may be considered to be 'legitimate', at least as far as the system of rules and procedures is concerned. Validity, or moral rightness, on the other hand, is a more demanding notion. Laws may be unjust even when they are legitimate. Thus a law which somewhat overtaxes a certain segment of the population may be said to be legitimate if a majority of the people decides on it. But it could be unjust for all that. Nevertheless, laws which severely infringe rights and liberties cannot be viewed as legitimate, even when they are passed by legitimate procedures. As Rawls goes on to say, laws cannot depart too far from justice if they are to claim legitimacy (Rawls 1993, 429). In other words, too much injustice has a corrupting effect on legitimacy.

With this distinction between validity and legitimacy in mind, let us begin by allowing (what is hopefully not a contentious claim) that decisions taken by solid majorities in democratic systems are expressive of the people's being sovereign. Or to be on the safe side, let us say that decisions taken by solid majorities or by consensus are expressive of the people's being sovereign. After all, in all such decisions the people are not accountable to any earthly agency; there is no court in which they can be held accomintable.

There are strands of democratic theory that betray an inclination to assimilate 'Validity', or moral rightness, to majoritarian-democratic legitimacy. It is as if one were to say: there is no meaning for the validity or rightness of political decisions apart from what is decided by the consensus of that community, or barring that, by solid maiorities. It is by no means obvious that this is an unacceptable position. Criteria for what is morally right or wrong are notoriously hard to come by. It is not obvious that we have access to notions of rightness and justice independent of social settings and 
historically conditioned arrangements to be discovered in specific political communities. According to Walzer,

We camnot say what is due to this person or that one until we know how these people relate to one another through the things they make and distribute ... A given society is just if its substantive life is lived in a certain way-that is, in a way faithful to the shared understandings of the members. (Walzer 1995, $312-13)$

This leads Walzer to conclude that 'Every substantive account of distributive justice is a local account' (Walzer 1995, 314). And if Walzer is right in his account of justice, one can certainly understand the temptation to identify rightness and justice with what the people (in solid majority, or in consensus) say they are. Thus the distinction between validity and legitimacy collapses. The price of this is (apparently) a certain kind of relativism. This is something which many thinkers accept.

Islamic (and other religious) thinkers do not accept collapsing the distinction between what is 'right' and what is merely 'legitimate' (on account of being passed by commonly accepted rules of procedure). Nor would they be comfortable with a definition of 'democratic legitimacy' that comes down to 'rule of the majority' with no conditions or restrictions attached. The suggestion which we want to put forward presently is to view Islamic thinkers' advocacy of divine sovereignty as a way of trying to go beyond this purely procedural view of democracy. We suggest that statements such as 'Sovercignty belongs to God', 'In an Islamic state only God rules', are to be viewed as statements about what political decisions ought to be like, if they are to have validity, or moral rightness. The idcal situation is when the democratic procedure functions within parameters set by divine law. Pcople can debate and discuss and finally, vote. Furthermore there is always a way to find out whether the decision was 'correct': not because it was accepted by the majority after discussion and debate, but by checking it against Sharīa.

According to this suggestion, statements to the effect that 'sovereignty belongs to God' contain a 'hidden ought': valid political decision ought to conform to divine law. But this is not the only 'ought' which lies hidden in such statements. Several authors have suggested that placing 'rulership' in the hands of God is also directed against the assimilation of 'validity' to autocratic procedures where political decisions are taken by sultans or kings who rule absolutely, and who are accountable to no one. Thus according to Hussain Ahmad Amin, this is how we ought to view the struggle over the Creation of the Qur'ān which took place during the time of the 'Abbāssid Caliph al-Ma'mün. 'To the Muslim 'ulamā', led by Ibn Hanbal, the question was whether the Caliph was to rule absolutely, or whether his rule was to be subject to objective, binding criteria of rightness. Giving precedence to divine law is a way of placing restriction on the will of earthly rulers (Amin 1987, 117). According to other writers the injunction of divine sovereignty can be looked at as an expression of anti-despotic tendencies (Bisharah 1993, 83), or as something that 'provides the conceptual and theological foundation for an active emphasis on equality within the political system' (Esposito \& Voll 1996, 25).

The explanation given above for the role which the notion of divine sovereignty plays in the thinking of some Islamic thinkers does not depend for its credibility on the terms which these thinkers employ to express their beliefs. The very effectiveness of appeals (o) 'divine government' depends precisely on removing, as much as possible, all traces of human operation. In other words, for the discourse of divine sovereignty to perform 
its function in the intellectual economy of political justification, it must appear to have extra-mundane reference.

Still, the explanation of divine sovereignty in terms of a need to go beyond procedure-based legitimacy is forced on us by the sheer implausibility of taking divine sovereignty literally. It makes little or no sense to take statements such as 'Sovereignty belongs to God' literally. Islamic thinkers who make such statements do not mean to imply that the Islamic state, unlike other mundane states, has an 'Invisible President' who rules as mundane potentates do. For this reason it strains credulity to find Bernard I ewis describing the Islamic state thus:

The Islamic state was in principle a theocracy-not in the Western sense of a state ruled by the Church and the clergy ... but in the more literal sense of a polity ruled by God. In principle, the state was God's state, ruling over God's people; the law was God's law ... (Lewis 1993, in Lipset 1994, 6, italics added)

Not only is this an uncharitable way of interpreting statements about the 'rule of God', it also fails to give a meaningful explanation of what is meant by 'the literal sense' of being ruled by God. Surely God does not sit on a throne issuing directives and reading reports. In Islam, as in other religions, people take it upon themselves to 'speak for God', usually by reference to 'divine texts'. Belief in the divinity of origin is not an cmpirically verifiable matter, and political action does not wait upon a scientific decision with respect to where God is, and what his present will is. As far as all practical (including political) purposes are concerned, belief in the divinity of texts simply means that they are in some sense placed above questioning. They are taken to have irrevocable authority, much as the principles which are embodied in a constitution that lays down the rules of the political game. Just as some political decisions may be judged 'unconstitutional', so can others be judged 'ungodly'. In either case 'validity' is not simply taken to be a matter of what the people say is right.

To sum up: endorsement of 'divine sovereignty' by some Islamic thinkers may be viewed as an attempt to provide criteria for political rightness or validity which go beyond factual procedures that vest legitimacy in the hands of the people or their rulers. We want now to see if the concerns which Islamic thinkers voice are peculiar to them, or if similar concerns can be found in contemporary Western political thought.

\section{Parallels in Western Political Thought}

Debates that are taking place now among political thinkers in the West about the nature of political legitimacy have yet to make an impact on Islamic understandings and discussions of democracy. Islamic thinkers are still inclined to identify democracy with models that have been variously called 'aggregative' (Cohen 1997, 111), 'pluralist', 'polyarchal' (Bohman \& Rehg 1997, Introduction) and 'procedural'. 'Procedural democracy' is defined by Estlund as 'the view that what makes democratic decisions legitimate is that they were produced by the fair procedure of majority rule' (Estlund 1997, 170).

Nevertheless, the more well-informed Islamic thinkers are gradually becoming aware of a tension between the explication of democracy as 'government of the people by the people', and a number of basic concepts and values, which democratic practice is supposed to express and respect, but which seem to have validity independently of popular acceptance. These include the values of individual autonomy, inalienable 
individual rights, equality, liberty, fairness, and other ideals of the democratic process. Democratic thinkers recognize that the unqualified concept of 'government by the people' does not always offer assurance that the people will respect the values mentioned above. Thus in his discussion of the possibility of a demos that intends to use the democratic process in order to end that very process, Dahl raises the question of 'whether the demos may rightly do what it clearly can do, or to use a different terminology, whether it has the authority to do what it has the power to do' (Dahl 1989, 181). The clear implication here is that it is logically possible for the popular will to go wrong, to will what is not right or just. But this means that Dahl has criteria of political rightness which are somehow set above the judgment of popular will.

What are these criteria? How do we know them? And what kind of authority do they have? Ghannouchi considers the status of basic liberal principles in contemporary Westem political theory, and he concludes that liberalism acknowledges the existence of 'principles higher than the human will':

All of these remarkable experiments in liberal thought concede the existence of principles that are higher than the human will, be this the will of the collectivity, or the will of the majority. In a number of cases hints at divine law' have been preserved... In fact, principles of Natural Law indicate that the human will has always been subject to a number of universally valid frameworks which it is not in a position to question. (Ghannouchi 1993, 70, 17. 289)

In making these claims Ghannouchi is echoing the self-perception which (some) Western thinkers have, as indicated by the results of their search for historical-cultural foundations of liberal beliefs. A particularly clear statement of this self-perception is made by Siedentop who claims to discover the notion of 'individual autonomy' in Christian thought. According to Siedentop:

The assumption that society consists of individuals, each with an ontological ground of his or her own, is a translation of the Christian premise of the equality of souls in the eye of God.... The birth of the individual was ... a Christian achievement (Siedentop 1989, 308; see Dahl 1989, 32-3).

The suggestion which I want to advance here is that Islamic thinkers, in their own way, may be trying to formulate a conception of a method of government where the democratic idea of popular sovereignty is combined (tempered, if you wish) with a moral view that rejects the identification of 'political rightness' with the mere counting of votes. There are at least two reasons which may incline Islamic thinkers to search for such a conception of government. The first is their belief in the cultural homogeneity of Islamic sociery. Such (presumed) homogeneity may suggest that democratic procedures are not utterly indispensable. The second is their view of procedure-independent validity as applied to collective decisions.

According to Estlund, aggregative (or purely procedural) views of democracy are most likely to find acceptance in communities which are characterized by cultural diversity, where there is much disagreement over standards of justice (Estiund 1997, 175). In the absence of shared understandings that can resolve conflicting interests, the only principle which people may be able to agree upon is that all interests should to be given equal consideration, with majority voting being the 'natural method' to achieve this (Cohen 1997, 111).

Islamic thinkers tend to believe that the Islamic political community is not characterized by division and disagreement over conceptions of justice and goodness. (It is an 
entirely different question whether this is indeed the case.) Hence, Islamic political life is likely to be less competitive and more consensual than, say, liberal communities. Voting becomes less of a contest, and more of a popular acclamation of policies on which members of the community see eye to eye.

More importantly perhaps, validity or 'moral rightness' of political decisions is not something that is known by voting. Whereas some would say that the rightness of the decision is defined by reference to the nature of the procedure which is used to arrive at it (namely, voting), Islamic thinkers would claim that rightness depends on the 'quality of the decision', as determined by procedure-independent means. In other words, theirs is what Estlund would call a 'correctness theory of legitimacy'. It is a member of a family of 'epistemic theories of legitimacy' which are united by their rejection of the assimilation of rightness to the method of arriving at decisions (Estlund 1997, 174). Estlund is critical of correctness theories, Rousseau's theory being the one which the discusses. According to him, 'if there existed epistemic standards then it would follow that some know better, and the knowers should rule, as in Plato's elegant and repellent republic' (Estlund 1997, 181). Estlund may be right in his rejection of 'cpistocracy', that is, the 'rule of the knowers'. But this is not the place to discuss the 'epistocratic' implications of Islamic reservations about democratic procedures. For our main aim is to suggest that Islamic thinkers are not unique in raising questions about the meaning and value of democratic procedures. Their adherence to 'divine sovercignty' should be viewed as an expression of their belief in the existence of standards and criteria for validity which are known independently of democratic procedures.

\section{Two Concepts of Sovereignty}

We finally come to the puzzling question of the type of 'authority' which Islamic thinkers attribute to criteria of political rightness which they are willing to set up as judge over the democratic process. We hope this will go some way towards clarifying the relationship between divine sovereignty and popular sovereignty. Reasons were presented above for rejecting the interpretation of divine sovereignty as 'direct divine rule'. This claim should be supplemented by saying that Islamic thinkers can (and many do) admit that there are at least two ways in which the people can be said to exercise power.

First, it is up to the people to accept or reject the divine message. As Khatimi says clearly, a stable, enduring Islamic state cannot come into existence if the people do not want it. This is simply common sense. We have no experience of 'divine states' being set up and maintained by divine powers, such as armies of angels and the like.

Second, people exercise power not just by choosing to live under 'divine law' at all, but also by choosing how to live under such a law. Divine messages are subject to interpretation, and the interpretation is invariably carried out by human agencies, even when people attribute everything they do to divine guidance (providence).

In these two very real ways, people are truly sovereign. All the ideas, principles, commands and injunctions that issue from 'the mouth of God' will remain inert, and utterly ineffective, so long as they do not dwell in the hearts and minds of people who are willing and able to act on them. The same applies to liberal principles, whose 'validity', in the eyes of Dahl and others, does not derive from popular acceptance. It makes no practical difference to human government whether the 'basic principles' have a divine origin, or if they have existence in some Platonic Moral Reality which human reason discovers. These principles are not active agents, or forces of nature. Hence they 
can do nothing until they come to be espoused by living human wills, until they come [o 'inform' human minds. At the same time, we are familiar with the substantive, vital and indispensable role which laws play in our lives. No one can seriously claim that our social-political life is merely a stage for the free play of lawless irrational human wills. This fact, I believe, will help us define a sense in which human will is subject to the 'authority of the law'. If we can do that then we shall be a position to describe not just one, but two scnses of sovereignty, in the following manner.

lirst, there is what we have referred to as 'factual sovereignty'. Sovereignty in this sense belongs to a 'free' people. A free people is sovereign in the sense of having the power to act in accordance with its will. Second, there is what we may call 'sovereignty in the formal sense', or 'formal sovereignty', for short. In a 'law-abiding society' this is the kind of 'sovereignty' enjoyed by laws, norms, or principles which meet the following conditions. First that they apply to everybody. People 'obey' them. Those who fail to do so are subject to sanctions. Second, that they are laws which people (generally speaking) believe in. They take them seriously, and act out of respect to them. Thirdly, these laws or norms are regarded as 'objectively right' or 'true'. They are not viewed as subjective inventions, or matters of community taste.

Should there be laws which enjoy such a status in a community, we would be right to speak of a community where the law is 'sovereign'. This is a perfectly harmless way of speaking, and it is generally not misleading. It does not mean that people's decisions and wills are ineffective, or non-existent; only that these wills and decisions follow non-arbitrary rules, rules that are regarded as objective and universal. To attach this interpretation to the notion of 'divine sovereignty' is a more charitable understanding of Islamic thinkers than the one which would have them deny that the people have any power to decide over anything, an idea which no reasonable person can believe. Islamic thinkers envision a political community where the people's will conforms with divine law. In such a situation the divine law will be 'supreme', but certainly not as an extemal, foreign principle which is rejected by the popular will.

Of course, it may be thought that the divine laws to be found in the Scriptures are 'divine inventions' of a willful God who could have ordained any set of laws for the human will to follow. But this is not a position which advocates of Islamic democracy have to accept as a matter of logic. For there are no compelling arguments to show that God is utterly incomprehensible to us. In fact, if that were the case then not only would belief in God be antithetical to reason, but we may also be unable to attach any meaning to the word 'God'. 'Thus we are not forced to say that what God 'invents' (if this is a good description of what He does) belongs to a different intellectual order from what the human reason can understand and accept.

It is certainly an open option for believers to think of God as akin to Moral Reality, so that (for example) Plato's Form of the Good could be viewed as God, or vice versa. In this way God definitely ceases to be something which is 'foreign' to the human mind. On the contrary, God's mind becomes something that we can 'see into'. But even if we wanted to stop short of 'internalizing God' in the aforementioned manner, there is no reason to think that God's authorship of the moral laws means that we cannot claim them as our own. Moral principles resemble arguments in the following way. You can discover an argument to prove a certain point, and that argument will be, in a straightforward sense, 'your argument'. But if I come to know of this argument and adopt it for myself, does it not become 'my argument' as well? The Argument from Design which I accept and use to defend my belief in God is my argument. I did not invent it, but this does not stand in the way of my calling it my own. It should be the 
same with moral principles. Principles cannot be owned any more than arguments, and the circumstance of this or that agent formulating, discovering or promulgating them first, is quite accidental to their essence.

Understood in the light of the distinctions and clarifications presented above, divine sovereignty, so-called, need not conflict with popular sovereignty. Islamic democracy may be a difficult concept to accept, but it must not be rejected on the basis of a supposed conflict between divine and popular sovereignty.

\section{REFERENCIES}

Anú 'AYD, Nasr Hämid (1994) Naqd al-khitāb al-dinn [Critique of Religious Discourse], Cairo, Sina li1-Nashr

Amin, Husayn Ahmad (1987) Datal al-maslim al-hazin [Sad Muslim's Guide], Cairo, Madbouli.

Bishakah, Azmi (1993) 'Madkhal li-mu'älajat al-dīmū crätiyya wa-amnat al-tadayyun' [Democracy and

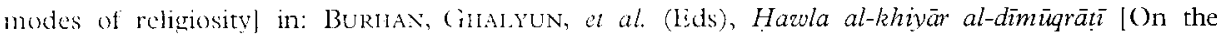
democratic ahternativel, $R$ ala, Muwàtin.

Bofmax, James \& Rehg, William (1ids) (1997) Deliberative Democracy: essays on reason and politics, (Cambridge, MA, Massachusetts Institute of Technology Press.

(omin, J. (1497) 'Procedure and substance in deliberative democracy', in: J. BOHMAN \& W. REHG, (liks), Deliberative Denocracy: essavs un reason and polites, Cambridge, MA, Massachusetts Institute of 'Technology press.

Difl, Robert (1989) Democracy and Its Cinics, New Haven, C"T, Yale University Press.

Istreste, John L. \& Voll, John O. (Leds) (1990) Islam and Domocracy, Oxlord, Oxford University Press. Estlund, David (1997) 'Beyond fairness and deliberation: the epistemic dimension of democratic authority', in: J. Bohman \& W. Ririg, (lids), Deliberative Democracy: essays on reason and politics, Cambridge, MA, Massachusetts Institute of Technology Press.

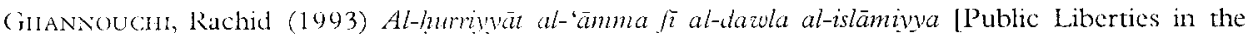
Islamic Statel, Beirut, Markaz Dirāsāt al-Wahda al-'Arabiyya.

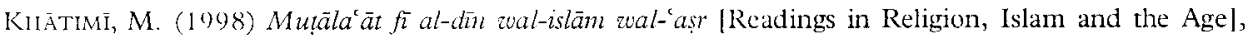
Bcirut, Dar al-Jadid

I liwis, Bernard (1993) 'Islam and liberal democracy', Atlantic Monthly 27(2) 89-98.

I I1'SYT, S.M. (1994) 'The social requisites of democracy revisited', American Sociological Reviev, 59 122

I 6)WRIE, Arthur (Ed.) (1993) Islan, Democracy, the State, and the West: a round table with Dr Hasan Twabi, Tampa, lil, The World of Islam Studies Enterprise.

RaWL, John (1943) Political Liberalism, New York, Columbia University Press.

Sibloneror', I..A. (1989) 'Liberalism: the Christian connection', Times Litcrary Supplemenl, March 2430 .

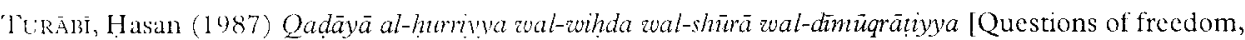
unity, consultation and democracyl, at-1)ār al-Sa ũdiyya lil-Nashr.

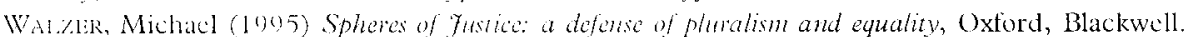

